\title{
PERAN RUMAH PEMBIAYAAN PERTANIAN KSM JAYA AMANAH DALAM MENGIMPLEMENTASIKAN INKLUSI KEUANGAN PETANI
}

\author{
(THE ROLE OF AGRICULTURAL FINANCING HOUSE OF KSM JAYA AMANAH \\ IN IMPLEMENTING FARMERS' FINANCIAL INCLUSION)
}

\author{
Selvi Jubaya*, Eliana Wulandari \\ Program Studi Agribisnis Fakultas Pertanian Universitas Padjadjaran \\ Jl. Raya Jatinangor Sumedang Km. 21 \\ *Email: selvijubaya66@gmail.com \\ (Diterima 18-11-2019; Disetujui 18-12-2019)
}

\begin{abstract}
ABSTRAK
Tingkat akses keuangan di Indonesia masih relatif rendah karena adanya beberapa hambatan yang dihadapi oleh para petani di Indonesia dalam mengakses lembaga keuangan formal. Kelompok Swadaya Masyarakat (KSM) Jaya Amanah merupakan salah satu lembaga yang berupaya mengimplementasikan inklusi keuangan petani melalui program pemberdayaan yaitu Rumah Pembiayaan Pertanian (RPP). Penelitian ini bertujuan untuk mengidentifikasi peranan KSM Jaya Amanah dalam mengimplementasikan inklusi keuangan di Kecamatan Pacet, Kabupaten Bandung. Metode analisis data yang digunakan adalah statistik deskriptif. Hasil analisis menunjukkan bahwa beberapa upaya telah dilakukan KSM Jaya Amanah dalam mengimplementasikan inklusi keuangan bagi para petani yaitu dengan adanya program RPP yang fokus memberikan akses keuangan bagi petani yang dianggap unbankable. Hadirnya RPP juga memberikan dampak positif terhadap hasil usahatani anggotanya. Hambatan yang dihadapi KSM Jaya Amanah dalam mengimplementasikan inklusi keuangan yaitu kurangnya dana dari investor dan sumber daya pengelola.
\end{abstract}

Kata Kunci: Inklusi Keuangan, Program Pemberdayaan, Rumah Pembiayaan Pertanian

\section{ABSTRACT}

The level of financial access in Indonesia is relatively low because of some obstacles that are faced by farmers in Indonesia to access formal financial institutions. KSM Jaya Amanah is one of the institutions that seeks to implement the financial inclusion of farmers through an empowerment program i.e the agricultural financing house. This research aims to identify the role of KSM Jaya Amanah in implementing financial inclusion in Pacet Subdistrict, Bandung District. Data analytical methods used in this research is descriptive statistics. The results of the analysis showed that several efforts have been made by KSM Jaya Amanah in implementing financial inclusion for farmers through the agricultural financing house program that focuses to provide financial access for farmers who are considered unbankable people. The agricultural financing house has a positive impact on the farm results of its members. The barriers faced by the KSM in implementing financial inclusion include lack of funds from investors and lack of the management resources.

Keywords: Financial Inclusion, empowerment program, Agricultural Financing House

\section{PENDAHULUAN}

Pada tahun 1998 telah terjadi krisis keuangan global di sejumlah negara termasuk Indonesia yang diikuti dengan krisis ekonomi pada tahun 2008. Krisis keuangan global kembali terjadi dan memuncak pada tahun 2011 di kawasan Eropa yang membuat perekonomian Eropa terpuruk. Sebaliknya, perekonomi- 
an di kawasan Asia justru mengalami pertumbuhan. Maka dari itu, krisis keuangan tersebut mengakibatkan beralihnya perekonomian dunia dari negara-negara Barat ke negara-negara Timur (Nengsih, 2015).

Menurut Cheng dan Degryse (2010), sektor keuangan baik perbankan maupun non-perbankan mampu mendorong pertumbuhan ekonomi yang tinggi. Nengsih (2015) menyatakan bahwa pertumbuhan ekonomi mengalami peningkatan karena adanya akses pelayanan perbankan yaitu dengan pemberian kredit. Namun, setelah krisis Eropa 2011 silam, pertumbuhan perekonomian Asia tidak didukung oleh peningkatan akses pelayanan terhadap lembaga keuangannya (Nugroho dan Evi, 2018).

Inklusi keuangan adalah keadaan dimana mayoritas individu dapat mengakses layanan keuangan tanpa biaya yang tinggi (Salim, 2014). Sistem inklusi keuangan tidak hanya menyediakan kredit tetapi juga bertujuan mengurangi kemiskinan sehingga tercapai pertumbuhan ekonomi yang lebih berkualitas (Ismawati, 2016). Menurut Bahri et al. (2018), inklusi keuangan merupakan topik penting yang dibahas dalam forum internasional seperti G20
(Group of Twenty), APEC (Asia-Pacific Economic Cooperation), AFI (Alliance for Financial Inclusion) dan ASEAN (Association of South east Asian Nations) bahkan telah diterapkan di berbagai negara. Namun, di Indonesia program tersebut baru diluncurkan pada tahun 2010 dengan tujuan untuk meminimalisir hambatan masyarakat dalam mengakses layanan keuangan.

Berdasarkan data Global Findex (Global Financial Inclusion Database) 2011, masyarakat Indonesia masih berada pada kategori rendah dalam mengakses layanan keuangan yaitu hanya 19,6 persen. Angka tersebut jauh berbeda dibandingkan negara-negara Asia lainnya seperti Thailand yang dapat mencapai 77,7 persen dan Malaysia sebesar 66,7 persen (Nengsih, 2015). Bahkan, apabila tingkat inklusi keuangan diukur melalui tiga indikator utama, Indonesia hanya mampu menduduki peringkat ke-empat untuk persentase kepemilikan rekening di lembaga keuangan formal (35,95 persen), peringkat ke-lima untuk persentase formal saving (26,56 persen) dan peringkat ke-tujuh untuk formal credit (13,3 persen). Inklusi keuangan di beberapa negara yang diukur berdasarkan tiga indikator utama dapat dilihat melalui grafik pada Gambar 1 


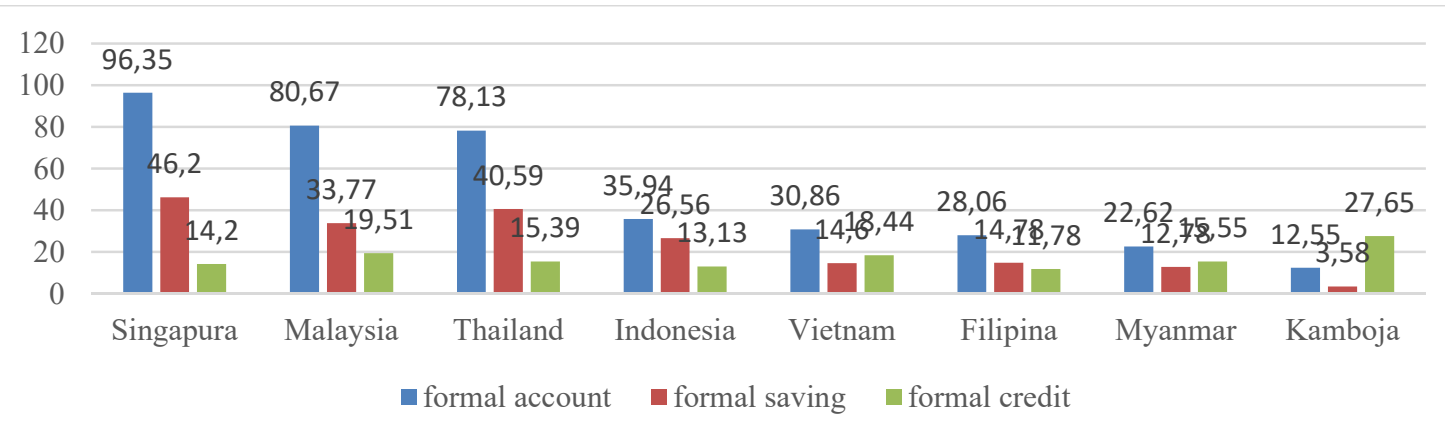

Sumber: Global Findex 2014, diolah

Gambar 1. Inklusi Keuangan di Beberapa Negara berdasarkan 3 Indikator Utama (dalam persen)

Rendahnya tingkat inklusi keuangan di Indonesia disebabkan beberapa hambatan dalam mengakses lembaga keuangan formal. Sulitnya mendapatkan akses pinjaman terutama dari lembaga keuangan formal sangat dirasakan oleh para petani di Indonesia. Menurut Asep (2016), dibandingkan sektor ekonomi lainnya, alokasi dana kredit untuk sektor pertanian kurang dari 10 persen dari total kredit yang disalurkan. Hal tersebut sejalan dengan data Statistik Perbankan Indonesia yang diterbitkan Otoritas Jasa Keuangan (2017), proporsi kredit untuk sektor pertanian dari perbankan nasional sebesar 6,61 persen. Padahal, sektor pertanian menyumbang kontribusi terbesar dalam penyerapan tenaga kerja di Indonesia yaitu sebesar 30,46 persen (BPS, 2018). Adapun proporsi penyaluran kredit perbankan nasional ditunjukkan melalui Tabel 1.
Tabel 1. Proporsi Penyaluran Kredit

\begin{tabular}{lc}
\hline \multicolumn{1}{c}{ Sektor Ekonomi } & $\begin{array}{c}\text { Porsi } \\
(\mathbf{\%})\end{array}$ \\
\hline Pertanian, Perburuan, Kehutanan & 6,61 \\
Perikanan & 0,23 \\
Pertambangan dan Penggalian & 2,73 \\
Industri Pengolahan & 17,47 \\
Pengadaan Listrik, Gas dan Air & 2,83 \\
Konstruksi & 5,21 \\
Perdagangan Besar dan Eceran & 18,82 \\
Penyediaan Akomodasi dan & 2,15 \\
Makan Minum & \\
Transportasi & 3,87 \\
Perantara Keuangan & 4,72 \\
Sumber: Otoritas Jasa Keuangan, 2017 &
\end{tabular}

Berdasarkan hal tersebut, diperlukan model pembiayaan alternatif sebagai upaya membuka akses permodalan khususnya bagi para petani. Beberapa penelitian menunjukkan bahwa funding dan financing pembiayaan syariah tahun 2010 - 2014 mengalami pertumbuhan yang signifikan. Artinya pembiayaan syariah memiliki potensi besar dalam mengimplementasikan financial inclusion (Mardani, 2018). Mahmoed Mohieldin et al. (2011) pun lebih menekankan pada pengimplementasian ekonomi syariah dibandingkan konvensional yang dapat 
menyebabkan kesenjangan ekonomi.

Oleh karena itu, pemerintah terutama di negara-negara muslim yang serius dalam mengimplementasikan financial inclusion atau inklusi keuangan perlu memanfaatkan potensi instrumen syariah seperti zakat, shadaqah dan qardul hasan untuk dapat mencapai tujuan dari inklusi keuangan. Hal tersebut diimplementasikan oleh Kelompok Swadaya Masyarakat (KSM) Jaya Amanah melalui program pemberdayaannya. KSM Jaya Amanah merupakan lembaga yang memanfaatkan dana zakat untuk menjalankan program bantuan akses permodalan bagi petani yang disebut Rumah Pembiayaan Pertanian (RPP). Program tersebut telah digulirkan di Kecamatan Pacet, Kabupaten Bandung.

Berdasarkan pemaparan latar belakang di atas, tujuan penelitian ini adalah untuk mengidentifikasi peranan KSM Jaya Amanah dalam mengimplementasikan inklusi keuangan di Kecamatan Pacet, Kabupaten Bandung.

\section{METODE PENELITIAN}

Penelitian ini dilakukan di KSM Jaya Amanah, Kecamatan Pacet, Kabupaten Bandung dengan mempertimbangkan bahwa KSM Jaya Amanah merupakan KSM yang bersinergi dengan LAZ Al Azhar dengan penerima manfaat terbesar di Jawa Barat.

Penelitian ini menggunakan data sekunder yang berasal dari KSM Jaya Amanah. Analisis data yang digunakan adalah analisis statistik deskriptif. Menurut Sugiyono (2017) statistik deskriptif digunakan untuk menganalisis dan mendeskripsikan data. Beberapa teknik statistik deskriptif yang dapat digunakan seperti data yang disajikan dalam bentuk tabel, visualisasi data melalui histogram, diagram batang dan diagram lingkaran. Adapun data yang digunakan pada penelitian ini adalah jumlah anggota KSM per periode, frekuensi pembiayaan, besarnya jumlah pembiayaan, dan jumlah produksi.

\section{HASIL DAN PEMBAHASAN}

Masyarakat saat ini telah dimudahkan dengan adanya sistem keuangan yang telah diatur oleh pemerintah. Maka dari itu, kini semua kalangan masyarakat dapat menabung atau menyimpan uang di lembaga keuangan. Namun, berbeda dengan sistem pembiayaan yang tidak semua kalangan masyarakat dapat menerima pembiayaan dari lembaga keuangan. Hal 
tersebut dikarenakan tidak semua masyarakat dianggap bankable atau mempunyai jaminan dan sebagainya. Oleh karenanya, pemerintah berupaya agar masyarakat yang unbankable pun dapat mengakses layanan finansial melalui program inklusi keuangan.

Karakter keuangan syariah memang sudah harus inklusif sejak dari awal sehingga inklusifitas yang sudah dibangun harus terus didorong dan dikembangkan. Hal tersebut bisa diupayakan sesuai dengan tingkatannya. Tingkatan pertama, yakni pemberian zakat diperuntukkan bagi masyarakat lemah atau golongan dhuafa dengan harapan dapat naik tingkatan menjadi golongan yang zakat-able. Setelah mampu membayar zakat, diharapkan masyarakat dapat mengakses layanan keuangan minimal pada lembaga keuangan mikro dan berlanjut sampai tingkatan masyarakat yang dapat mengakses lembaga keuangan formal atau masyarakat yang bankable.

\section{Gambaran Umum Kelompok Swadaya Masyarakat (KSM) Jaya Amanah}

Kelompok Swadaya Masyarakat (KSM) Jaya Amanah merupakan sebuah lembaga pemberdayaan masyarakat yang berorientasi pada pengentasan kemiskinan. Berdirinya lembaga ini, berawal dari pemberdayaan santri di Pondok Pesantren Al-Ikhlas Manarul Huda. Pemberdayaan para santri dimulai dari bidang peternakan dan pertanian hingga menyebarluas di kalangan masyarakat. Kemudian, lembaga ini bekerja sama dengan Lembaga Amil Zakat (LAZ) Al Azhar dan terbentuk kelompok yang diberi nama Kelompok Swadaya Masyarakat (KSM) Jaya Amanah. KSM Jaya Amanah resmi berdiri pada 4 Mei 2014 yang berlokasi di Kampung Paninggaran, Desa Mekarjaya, Kecamatan Pacet, Kabupaten Bandung. Pada awal didirikan, KSM Jaya Amanah memiliki perangkat organisasi yang sederhana yaitu terdiri dari ketua, bendahara, sekretaris dan 45 orang anggota.

KSM Jaya Amanah bersama LAZ Al Azhar menginisiasikan tiga program pemberdayaan dengan tiga bidang yang berbeda yaitu pertanian, peternakan, dan Usaha Mikro Kecil dan Menengah (UMKM). Adapun konsep dasar dari seluruh program yang dimiliki terdiri atas empat tahapan yaitu penyelamatan, penguatan (qardhul hasan), pengembangan, dan ketahanan.

Salah satu program unggulan KSM Jaya Amanah yaitu Rumah Pembiayaan Pertanian (RPP) yang merupakan 
program pemberdayaan di bidang pertanian. Perkembangan Kelompok Swadaya Masyarakat Jaya Amanah pada tahun 2019 semakin pesat. Hal tersebut dapat dilihat dari bertambah besarnya jumlah kelompok penerima manfaat dan nilai manfaat yang bisa diberikan. Para anggota mulai merasakan kemudahan dalam mengakses pembiayaan yang berbasis syariah melalui dana Qard yang dikelola oleh para pengurus KSM.

\section{Implementasi Inklusi Keuangan pada KSM Jaya Amanah}

Ada beberapa tahapan yang telah dirumuskan dari program pemberdayaan yang dilakukan oleh KSM Jaya Amanah dalam mengimplementasikan inklusi keuangan, terutama dalam memberikan pembiayaan bagi para petani melalui Rumah Pembiayaan Pertanian (RPP) yaitu:

a. Penyelamatan. Pendayagunaan zakat yang digunakan untuk memenuhi kebutuhan dasar bagi keluarga extrim poverty.

b. Penguatan. Penguatan ekonomi melalui pinjaman bergulir (qardhul hasan). Pinjaman tersebut digunakan untuk modal usaha produktif. Tahun pertama, murni pinjaman yang diberlakukan tabungan dan dana tabarru. Tahun kedua, diberikan pinjaman yang disertai dengan pemberlakuan dana administrasi (ujroh). Tahun ketiga, pemberlakuan akad jual beli dan bagi hasil. Terakhir, para petani yang diberikan pinjaman dapat mendirikan Kelompok Usaha Bersama (KUB).

c. Pengembangan. Pada tahapan ini, para petani sudah mendapatkan akses keuangan sehingga bisa digunakan untuk meningkatkan produktivitas usahanya. Selain itu, KSM Jaya Amanah juga menyediakan akses pemasaran melalui Kelompok Usaha Bersama sehingga para petani bisa menjual atau memasarkan hasil panennya ke KSM.

d. Ketahanan. Para petani diharapkan mampu mempertahankan kondisi sampai tahap ini. KSM Jaya Amanah juga mengadakan tabungan jangka panjang dalam rangka mempersiapkan kebutuhan keuangan di masa depan. Selain itu, para petani juga diharapkan terus mengembangkan usahanya agar penghasilan yang meningkat dapat digunakan untuk berinvestasi sebagai wujud ketahanan. 
Adapun upaya yang telah dilakukan KSM Jaya Amanah dalam rangka mengimplementasikan inklusi keuangan adalah sebagai berikut:

a. Melakukan sosialisasi kepada para petani padi sawah dan palawija untuk meningkatkan perekonomian dan mengupayakan pengembangan usahatani petani melalui RPP. Dengan adanya RPP, modal para petani menjadi bertambah sehingga diharapkan mampu meningkatkan hasil produksi dan pendapatan mereka. Adapun skema pembiayaan yang ditawarkan KSM Jaya Amanah melalui RPP ditunjukkan pada Gambar 2.

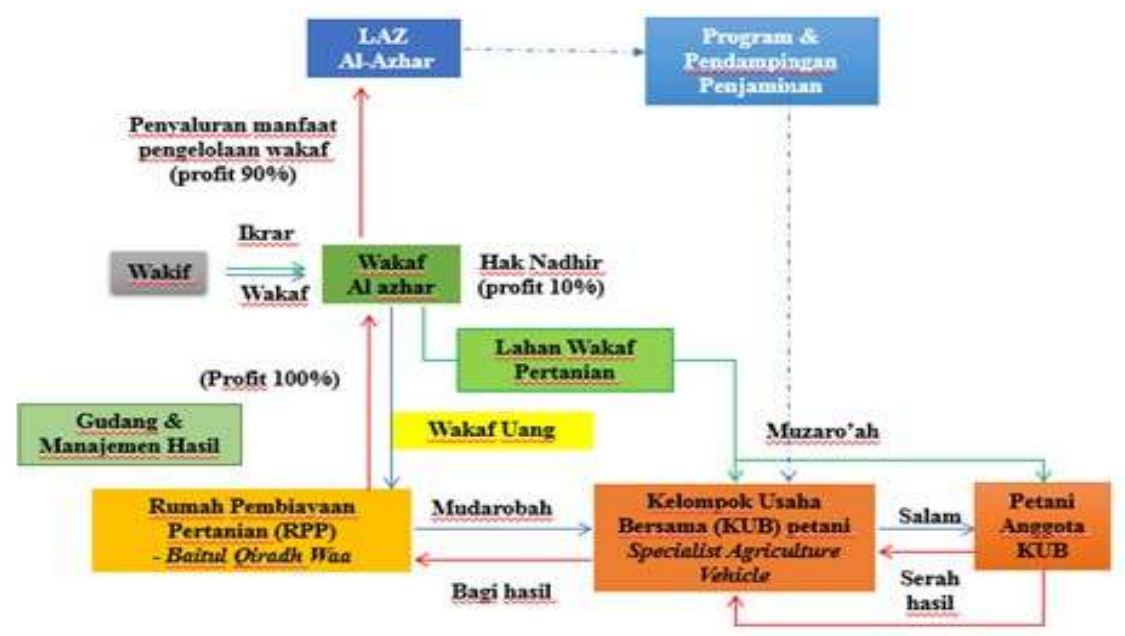

Gambar 2. Skema Pembiayaan Melalui Rumah Pembiayaan Pertanian

Para pengelola KSM berkeyakinan bahwa dengan program RPP, KSM dapat berperan secara signifikan dalam mengimplementasikan inklusi keuangan. Hal ini disebabkan ketika para petani tidak dapat mengakses kredit pada jasa keuangan formal karena tidak memenuhi persyaratan yang diberikan (unbankable), maka pada saat ini KSM berperan dalam membuka akses pembiayaan bagi para petani untuk mengembangkan usahataninya.

Jumlah penerima pembiayaan yang telah diberikan oleh KSM Jaya Amanah di Desa Cinanggela dan Desa Pangauban periode 2015-2018 disajikan pada Gambar 3. 


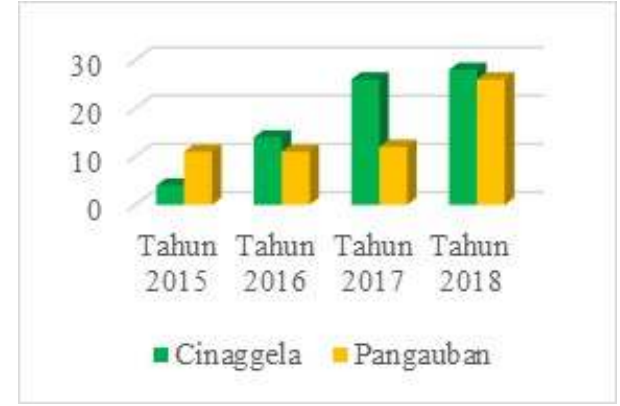

Sumber: KSM Jaya Amanah, data diolah Gambar 3. Jumlah Anggota Penyaluran RPP Tahun 2015-2018

Berdasarkan Gambar 3 dapat dilihat bahwa anggota yang dibiayai baik di Desa Cinanggela maupun Desa Pangauban oleh KSM Jaya Amanah melalui RPP setiap tahunnya semakin bertambah. Pada tahun 2015, jumlah anggota yang dibiayai sebanyak 15 anggota, meningkat di tahun 2016 menjadi 25 anggota, dan 38 anggota di tahun 2017 serta di tahun 2018 menjadi 54 orang anggota. Hal tersebut menggambarkan bahwa KSM Jaya Amanah telah berupaya mengimplementasikan inklusi keuangan kepada para petani.

b. Produk yang dipasarkan adalah Rumah Pembiayaan Pertanian (RPP). Produk tersebut menggunakan salah satu akad syariah yang sangat cocok dengan karakter sektor pertanian yaitu akad salam. Akad salam merupakan alternatif pembiayaan yang cocok dengan keadaan petani Indonesia. Mayoritas petani Indonesia bermodal kecil dan baru dapat membayar pinjaman modal ketika panen tiba. Akad salam merupakan akad jual beli barang dengan sistem pesanan dimana barang pesanannya dibiayai dimuka sedangkan barangnya diserahkan kemudian dengan waktu yang telah disepakati (Widiana dan Annisa, 2017).

c. Pembiayaan melalui RPP dilakukan sebanyak dua kali musim tanam dalam satu tahun. Periode pertama yaitu pembiayaan diberikan pada bulan Desember untuk masa tanam Januari hingga April. Periode kedua, pembiayaan diberikan pada bulan Juni untuk masa tanam Juli hingga Oktober. Frekuensi pembiayaan yang diberikan ditunjukkan pada Gambar 4.

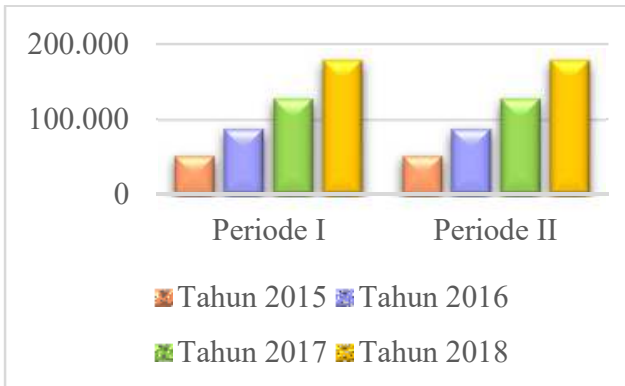

Sumber: KSM Jaya Amanah, data diolah Gambar 4. Frekuensi Penyaluran RPP Tahun 2015-2018 (Rp '000)

Berdasarkan Gambar 4, KSM Jaya Amanah menyalurkan dana dengan jumlah yang sama pada kedua periode. Semakin banyak anggota yang tergabung dalam RPP maka 
dana yang digulirkan setiap tahunnya semakin besar.

d. Besarnya jumlah pembiayaan yang diberikan oleh KSM Jaya Amanah melalui RPP disesuaikan dengan besarnya luas lahan yang dimiliki. Jumlah pinjaman yang diberikan maksimal 50 persen dari total hasil panen yang diperoleh. Hal ini dikarenakan KSM Jaya Amanah berharap bahwa setidaknya setiap anggota mampu memenuhi kebutuhan pangan yang berasal dari hasil panennya sendiri.

\section{Inklusi Keuangan melalui Rumah Pembiayaan Pertanian}

Desa Pangauban dan Desa Cinanggela merupakan dua desa yang menerima pembiayaan RPP dari KSM Jaya Amanah. Kedua desa tersebut sebagian besar hanya mengandalkan modal pribadi dan pinjaman dari rentenir. Bahkan, angka pinjaman dari rentenir pada kedua desa tersebut cukup tinggi. Oleh karena itu, KSM Jaya Amanah hadir dengan program Rumah Pembiayaan Pertanian dalam rangka membuka akses layanan keuangan yang lebih berkualitas dan bertanggung jawab. Kini petani yang dianggap unbankable tetap bisa mengakses layanan keuangan melalui RPP. Dengan demikian, KSM Jaya
Amanah melalui program RPP turut berupaya dalam mengimplementasikan inklusi keuangan petani khususnya bagi kedua desa tersebut.

Selain memberikan bantuan permodalan, KSM juga memberikan pendampingan mengenai sistem semi organik sehingga dana yang diberikan melalui RPP kepada para petani memberikan dampak positif pada hasil produksi usahatani. Berdasarkan Gambar 5, hasil produksi dari 63 persen petani anggota mencapai 1,2 ton gabah kering yang sebelumnya hanya mampu menghasilkan 0,95 ton gabah kering. Pada tahun 2018, total hasil produksi para petani di kedua desa sebesar 68.900 kg. Artinya, rata-rata petani mampu menghasilkan panen sebesar $1.300 \mathrm{~kg}$ atau 1,3 ton.

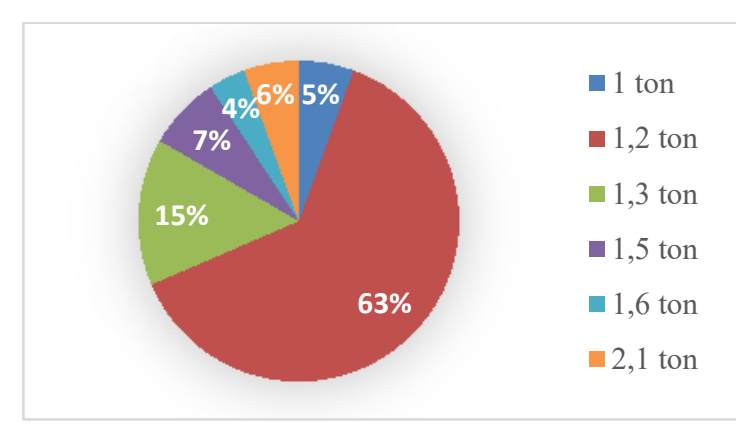

Sumber: KSM Jaya Amanah, data diolah Gambar 5. Hasil Produksi Anggota RPP Tahun 2018

\section{Hambatan Mengimplementasikan Inklusi Keuangan}

Hambatan yang dihadapi oleh KSM Jaya Amanah dalam mengimplementasikan inklusi keuangan yaitu: a) 
Pertambahan anggota KSM belum bisa dilakukan karena jumlah asset atau dana yang dimiliki belum cukup untuk membiayai calon anggota baru. Padahal, sudah banyak calon anggota yang berminat untuk bergabung ke dalam RPP KSM Jaya Amanah; b) Masih terdapat kekurangan sumber daya manusia sebagai pengelola KSM sehingga bantuan permodalan RPP belum bisa menjangkau masyarakat dengan jarak lokasi yang jauh. Selebihnya, tidak ada hambatan yang begitu berarti mengenai permasalahan pengembalian dana walaupun KSM tidak memberlakukan adanya jaminan. Hal ini dikarenakan KSM menerapkan sistem tabungan sukarela yang digunakan untuk mengantisipasi apabila terjadi keterlambatan pengembalian dana baik karena kegagalan panen atau karena hal lain.

Rencana strategis ke depan yang akan dilakukan KSM Jaya Amanah diantaranya: a) Menarik para investor untuk memberikan suntikan dana pada program RPP sehingga dapat meningkatkan jumlah aset atau modal untuk disalurkan kembali kepada para petani yang membutuhkan; b) Menambah jumlah anggota pengelola KSM sehingga dapat lebih menjangkau lapisan masyarakat sampai ke pelosok desa.

\section{KESIMPULAN DAN SARAN}

Kelompok Swadaya Masyarakat (KSM) Jaya Amanah telah berupaya mengimplementasikan inklusi keuangan melalui pelaksanaan Rumah Pembiayaan Pertanian (RPP). Anggota RPP yang dibiayai oleh KSM setiap tahunnya semakin bertambah hingga tahun 2018 mencapai 54 orang petani. RPP merupakan program pembiayaan dengan menggunakan salah satu akad syariah yang sangat cocok dengan karakter sektor pertanian yaitu akad salam. Pembiayaan RPP ini dilakukan dua semester dalam satu tahun dengan besaran pembiayaan yang diberikan disesuaikan dengan besarnya luas lahan yang dimiliki masing-masing anggota. Hadirnya RPP juga memberikan dampak positif terhadap hasil usahatani anggotanya. Hambatan yang dihadapi oleh KSM Jaya Amanah dalam mengimplementasikan inklusi keuangan yaitu jumlah aset atau dana yang dimiliki belum cukup untuk membiayai calon anggota baru dan kurangnya sumber daya pengelola KSM sehingga bantuan permodalan RPP belum bisa menjangkau masyarakat dengan jarak lokasi yang jauh. 


\section{DAFTAR PUSTAKA}

Asep, N. (2016). Sistem Keuangan Pedesaan dan Pertanian Melalui Peran Lembaga Keuangan Mikro (LKM) Syari'ah (BMT: Alternatif Model LKM Syari'ah). Mimbar Agribisnis, 1(3): 181-196.

Badan Pusat Statistik. (2018). Keadaan Ketenagakerjaan Indonesia Februari 2018. Badan Pusat Statistik, Jakarta.

Bahri, A.R., Fathoni, A., \& Gagah, E. (2018). Model Inklusi Keuangan Terhadap Arah Pengembangan Nilai CSR Perbankan (Studi Kasus Program CSR BNI 46 di Usaha Batik Lasem). Jurnal Management, 4(4): 1-13.

Cheng, X., \& Degryse, H. (2010). The Impact of Banks and Non-Bank Financial Institutions on Local Economic Growth in China. Journal of Financial Services Research, 37(2): 179-199.

Demirguc-Kunt, A., Klapper, L., Singer, S., \& Oudheusden, P. V. (2015).

The Global Findex Database 2014 Measuring Financial Inclusion Around the World.Policy Research Working Paper World Bank. Washington, DC. no WPS. 7255.

Ismawati. (2016). Persepsi Usaha Mikro dan Kecil terhadap Inklusi Keuangan dan Akses Perbankan. Artikel Ilmiah. Sekolah Tinggi Ilmu Ekonomi Perbanas. Surabaya.

Mardani, D.A. (2018). Peran Perbankan Syariah Dalam Mengimplementasikan Keuangan Inklusif di Indonesia. Journal of Islamic Studies, 1(1): 105-120.
Mohieldin, Mahmoed., Rostom, A., Iqbal, Z., \& Fu, X. (2011). The Role of Islamic Finance in Enhacing Financial Inclusion in Organization of Islamic Cooperation (OIC) Countries. Policy Research Working Paper World Bank. Washington, DC. no WPS. 5920.

Nengsih, N. (2015). Peran Perbankan Syariah dalam Mengimplementasikan Keuangan Inklusif di Indonesia. Jurnal Etikonomi, 14(2): 221-240.

Nugroho, A \& Purwanti, E. Y. (2018). Determinan Inklusi Keuangan di Indonesia (Global Findex 2014). Jurnal Dinamika Ekonomi Pembangunan, 1(1): 1-13.

Otoritas Jasa Keuangan. (2017). Statistik Perbankan Indonesia: Laporan Profil Industri Perbankan Triwulan II 2017. Otoritas Jasa Keuangan, Jakarta.

Salim, M. (2014). Analisis Implementasi Program Financial Inclusion di Wilayah Jakarta Barat dan Jakarta Selatan (Studi pada Pedagang Golongan Mikro, Instansi Perbankan, Otoritas Jasa Keuangan dan Bank Indonesia). [skripsi]. Universitas Bina Nusantara.

Sugiyono. (2017). Metode Penelitian Kuantitatif, Kualitatif, dan R\&D. Bandung: Alfabeta.

Widiana \& Annisa, A.A. (2017). Menilik Urgensi Penerapan Pembiayaan Akad Salam pada Bidang Pertanian di Lembaga KeuanganSyariah di Indonesia. Jurnal Ekonomi dan Perbankan Syariah, 8(2):88-101. 